\title{
THE DISTRIBUTION OF IRON IN IRON-ENRICHED CELLS OF SACCHAROMYCES CEREVISIAE
}

\author{
H. GAUDREAU ${ }^{\mathrm{a}}$, T. A. TOMPKINS ${ }^{\mathrm{b}}$ and C. P. CHAMPAGNE ${ }^{\mathrm{a} *}$ \\ ${ }^{\mathrm{a}}$ Food Research and Development Center, Agriculture and Agri-Food Canada, \\ 3600 Casavant Blvd. West, Saint-Hyacinthe (Quebec) J2S 8E3. Canada \\ ${ }^{b}$ Lallemand Inc., 1620 Préfontaine Street, Montréal (Quebec) H1W 2N8. Canada
}

(Received: 25 October 2000; accepted: 21 June 2001)

Fresh or freeze-dried iron-enriched bakers' yeast (5\% of total solids composed of iron) were fractionated, and the distribution of iron was examined. After centrifugation of fresh yeast creams, $89 \%$ of total iron was found in the supernatant, which contained only $23 \%$ of the total solids. Results suggest that only $13 \%$ of the iron is bound to cells in the fresh yeast suspension. Most of the cell-located iron was found on the cell wall, whereas the cytoplasm contained proportionally (iron content of total solids) almost 3 times less iron than the cell walls. Freezedrying of the iron-enriched yeast had marked effects on the distribution of total solids and iron (in the fractionation procedures that were carried out following their rehydration). The freezedrying process induced binding of free iron to the yeast cell wall, and twice as much iron was thus found on freeze-dried cells. In the freeze-dried product, it was estimated that $27 \%$ of iron was bound to cell fractions.

Keywords: adsorption, drying, minerals, yeast

Iron has important functions in the human body. It is needed to form hemoglobin in blood and myoglobin in muscles. A deficiency in iron may result in anaemia (NESTEC, 1987).

Inorganic iron salts as inorganic chromium salts (HEGÓCZKI et al., 1997) may not be as readily absorbed or biologically active as organic forms of minerals. Microelements from organic sources, particularly yeast, have better absorption quotients and are less toxic than those obtained from inorganic sources (HEGÓCZKI, 1994). Microorganisms accumulate metals by a number of different processes such as uptake by transport, biosorption to cell walls and entrapment in extracellular capsules,

* To whom correspondence should be addressed.

Telephone: (450) 773-1105; Fax: (450) 773-8461; E-mail: CHAMPAGNEC@EM.AGR.CA

0139-3006/2001/\$ 5.00 @ 2001 Akadémiai Kiadó, Budapest 
precipitation and oxido-reduction reactions (BRADY \& DUNCAN, 1994). The organically bound form of chromium found in yeasts is known to be both assimilable and efficient as a dietary source of chromium (HEGÓCZKI et al., 1997).

Many mineral-enriched yeasts, also called organic mineral yeast, are available on the market. The production of mineral-enriched yeast often requires specific growth conditions (NAGODAWITHANA \& GUTMANIS, 1985), but most processes are unpublished and proprietary. Little is known on the distribution of the minerals in or at the surface of the cell. Various metals are assimilated by Saccharomyces cerevisiae (BRADY \& DUNCAN, 1994) and some, such as selenium, are incorporated into amino acids (MATNI et al., 1995). There is little information, however, on the distribution of iron in commercial iron-enriched Saccharomyces cerevisiae cells.

The aim of this study was to evaluate the rate of iron binding to cell organic compounds and to determine the effect of drying on iron bound to Saccharomyces cerevisiae.

\section{Materials and methods}

\subsection{Yeasts}

A fresh concentrated (20\% solids) commercial Saccharomyces cerevisiae TC1 suspension (Lallemand Inc. Montréal, Canada) was supplemented by $48.4 \mathrm{~g} \mathrm{l}^{-1}$ of $\mathrm{FeSO}_{4} \cdot 7 \mathrm{H}_{2} \mathrm{O}$, and incubated $1 \mathrm{~h}$ at $25^{\circ} \mathrm{C}$ under rapid stirring. Half of the yeast cell suspension was used immediately while the other was frozen at $-40{ }^{\circ} \mathrm{C}$ in a cabinet freezer and then freeze-dried at $24^{\circ} \mathrm{C}$ for $72 \mathrm{~h}$ (Lyo San Inc., Lachute, Canada) under a vacuum of at least $100 \mu \mathrm{m}$ of $\mathrm{Hg}$ ( 0.1 Torr). The powder was rehydrated in deionized water at $20 \%$ solids before fractionation.

\subsection{Fractionation of yeasts components}

The fractionation steps are presented in Fig. 1. Yeasts suspensions were centrifuged at $15000 \mathrm{~g}$ during $15 \mathrm{~min}$. The pellet was washed with deionized water and centrifuged again for $15 \mathrm{~min}$. The supernatant and the wash water were pooled and the material was thoroughly stirred. This material was pre-filtered on a $8 \mu \mathrm{m}$ Whatman (No. 2 filter paper) membrane and further processed by ultrafiltration (UF) using a tangential filtration system (Minitan Filter plates, Millipore, Bedford, USA) with membranes having 1000 Da molecular cut-off. A $500 \mathrm{ml}$ supernatant solution was used, and the UF process was stopped after the recovery of $300 \mathrm{ml}$ of filtrate.

The cell pellet obtained from the first centrifugation was resuspended with deionized water and cell disruption was conducted in a mixer mill type MM2 (Retsh, Haan, Germany) in nylon $180 \mathrm{ml}$ vessels according to the method used by MORIN and co-workers. (1993). Disruption was made at 100\% intensity during $25 \mathrm{~min}$. 


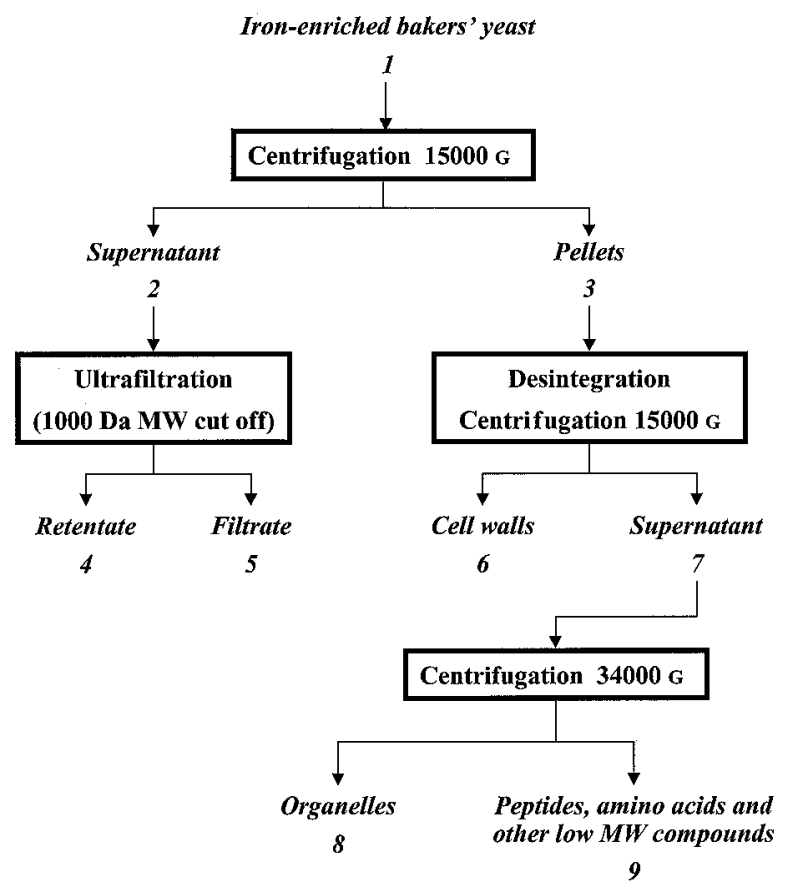

Fig. 1. Fractionation steps of the iron-enriched bakers' yeast cell suspension

Differential centrifugation based on the methodology of VARIMO and co-workers. (1983) was used to separate disintegrated yeast components. Disrupted cells solutions were centrifuged at $15000 \mathrm{~g}$ during $15 \mathrm{~min}$ and the supernatants were again centrifuged at $34000 \mathrm{~g}$ during $15 \mathrm{~min}$ with the aim of separating organelles, such as mitochondria and microsomes, from other constituents. The supernatant should contain soluble proteins, nucleic acids and peptides, amino acids, salts and other small molecular weight compounds (VARIMO et al., 1983). Fractionation of fresh iron-enriched yeast cells was completely replicated two times. One assay was carried out for the dried product.

\subsection{Chemical analyses of yeast cell fractions}

1.3.1 Solids content. Total solids content of all fractions were obtained by dry weights after incubation at $105^{\circ} \mathrm{C}$ for $16 \mathrm{~h}$. The assays were done in duplicate on each sample and the mean of the obtained values was used. Relative standard error on mean for the solids analyses was $<2.1 \%$. Fractionation of fresh iron-enriched yeast cells was done two times and relative standard error on mean on data of the two experiments was less than $9 \%$. 
1.3.2 Iron concentration determination. Crucibles were pre-soaked in hydrochloric acid $(\mathrm{HCl}, 10 \%)$ for two hours, rinsed with deionized water and dried in a $550{ }^{\circ} \mathrm{C}$ oven for one hour. They were removed from the oven and placed in a desiccator for $30 \mathrm{~min}$. Samples $(2 \mathrm{~g})$ were added to the cooled crucibles. Samples were dried at $105{ }^{\circ} \mathrm{C}$ and then ashed at $550{ }^{\circ} \mathrm{C}$ for at least $16 \mathrm{~h}$. The ash-containing crucibles were cooled in a desiccator for $30 \mathrm{~min}$ and weighed when they reached room temperature. The ashes were dissolved in $10 \mathrm{ml}$ of concentrated $\mathrm{HCl}$, which was then evaporated to dryness on a hot plate. The residue was redissolved by adding $10 \mathrm{ml}$ of concentrated $\mathrm{HCl}$. The iron concentration was measured in this solution by atomic absorption with a Varian SpectrAA-100 (Malgruve, Victoria, Australia) unit. A specific hollow cathode lamp (model 3QNY-Fe, Cathodeon Limited, Cambridge, UK) and $372.0 \mathrm{~nm}$ wavelength were used to determine iron concentration in the solution. The assays were done in duplicate on each sample and the mean of the obtained values was used. Relative standard error on mean was less than $5.4 \%$ for the measurement of iron when multiples analyses were conducted on a given sample. Fractionation of fresh iron-enriched yeast cells was done two times and relative standard error on mean on data of the two experiments was slightly less than $12 \%$.

\section{Results and discussion}

\subsection{Fresh yeast cell suspensions}

The distribution of iron and total solids in fresh yeast cell fractions is shown in Table 1. Total iron in initial yeast creams was $10 \mathrm{~g} \mathrm{l}^{-1}$ and represented the $100 \%$ level. After centrifugation of fresh yeast creams, most (89\%) of total iron was found in the supernatant, while this fraction constituted only $23 \%$ of total solids. Ultrafiltration results of the supernatant fraction suggest that the iron did not bind to a great extent to high-molecular weight components, since the percentage of iron of the total solids was lower in the retentate (fraction 4) than in the filtrate (fraction 5). The sample that had the highest proportional content in iron was the filtrate (fraction 5). Therefore, most of the iron added to the yeast cream was not bound, and it was found that only $13 \%$ was attached to or absorbed by the yeast cells. It will be noted that the sum of iron in samples 2 and 3 was greater than that in the original sample by $2 \%$, and this is a reflection of the experimental error in the atomic absorption analyses.

A significant portion of the iron was absorbed, although an incubation of only $1 \mathrm{~h}$ was carried out, since the cytoplasm solids (fraction 7) contained 3\% of the iron added to the cell suspension. Most of the cell-located iron was found on the cell wall (fraction 6). 
Table 1

Distribution of iron and total solids contents in different yeast cell fractions

\begin{tabular}{|c|c|c|c|c|c|c|c|c|c|c|}
\hline \multirow{3}{*}{ Fraction $^{\mathrm{a}}$} & \multicolumn{5}{|c|}{ Fresh yeasts } & \multicolumn{5}{|c|}{ Dried yeasts } \\
\hline & \multicolumn{2}{|c|}{ Iron } & \multicolumn{2}{|c|}{ Total solids } & \multirow{2}{*}{$\begin{array}{l}\mathrm{Fe} \% \\
\text { of } \mathrm{TS}^{\mathrm{c}}\end{array}$} & \multicolumn{2}{|c|}{ Iron } & \multicolumn{2}{|c|}{ Total solids } & \multirow{2}{*}{$\begin{array}{l}\mathrm{Fe} \% \\
\text { of TS }\end{array}$} \\
\hline & $\mathrm{g} \mathrm{l}^{-1}$ & $\%^{\mathrm{b}}$ & $\mathrm{g} \mathrm{l}^{-1}$ & $\%$ & & $\mathrm{~g} \mathrm{l}^{-1}$ & $\%$ & $\mathrm{~g}^{-1}$ & $\%$ & \\
\hline 1 & 10 & 100 & 200 & 100 & 5.0 & 10 & 100 & 200 & 100 & 5.0 \\
\hline 2 & 8.9 & 89 & 46 & 23 & 19 & 7.0 & 70 & 48 & 24 & 15 \\
\hline 3 & 1.3 & 13 & 150 & 75 & 0.8 & 2.7 & 27 & 130 & 65 & 2.1 \\
\hline 4 & 3.1 & 31 & 38 & 19 & 8.1 & 3.8 & 38 & 52 & 26 & 7.3 \\
\hline 5 & 5.3 & 53 & 26 & 13 & 20 & 2.2 & 22 & 34 & 17 & 6.5 \\
\hline 6 & 0.9 & 9.0 & 82 & 41 & 1.1 & 2.2 & 22 & 96 & 48 & 2.2 \\
\hline 7 & 0.3 & 3.0 & 72 & 36 & 0.4 & 0.6 & 6 & 42 & 21 & 1.0 \\
\hline 8 & 0.03 & 0.3 & 10 & 5.0 & 0.1 & 0.08 & 0.8 & 0.1 & 0.5 & 80 \\
\hline 9 & 0.3 & 2.5 & 54 & 27 & 0.4 & 0.4 & 3.5 & 42 & 21 & 0.8 \\
\hline
\end{tabular}

a: Fractionation steps are listed in Fig. 1

b: percentage of the quantity initially added

c: $\mathrm{Fe} \%$ of $\mathrm{TS}=$ percentage of total solids represented by iron in the given fraction

These results are in accordance with those of МосноBA and co-workers (1996a) who demonstrated that $\mathrm{Fe}^{++}$appeared at higher concentrations in the mannoprotein fractions than in the intracellular fractions of brewing strain of Saccharomyces cerevisiae. The storage site of iron in brewing strain was proposed to be the mannoprotein layer of the cell wall (МосновA et al., 1996a). The cell wall is an important site of initial biological interaction between cells and external metal ions (МосновA et al., 1996b).

With respect to the cytoplasm, iron constituted a lower proportion of total solids in the organelles (fraction 8) than in the rest of the cytoplasm. This suggests that most of the iron that was absorbed by the yeast was still free inside the cell.

\subsection{Effect of freeze-drying}

Freeze-drying of the iron-enriched yeast cell suspension had marked effects on the distribution of total solids and iron in the fractionation procedures that were carried out following rehydration (Table 1).

It can first be observed that the supernatant obtained from the initial centrifugation (fraction 2) of the freeze-dried cells has a lower iron content than that of the fresh yeasts. Thus only $70 \%$ of the iron initially added was found in the supernatant of the rehydrated cells (fraction 2), while iron constituted $89 \%$ of the fresh yeast suspension total solids. Inversely, a higher iron content was found in the cell pellet of the rehydrated cells. 
A slightly lower iron content in solids is found in the supernatant obtained following the first centrifugation (fraction 2) with the previously dried cells (19\% for fresh VS 15\% for dried). Presumably, freezing and drying of the cells damaged the cell walls and enabled leakage of intracellular components. This hypothesis finds support in the fact that a significant reduction in solids was noted for the intracellular portion (fraction 7) when the cells had been dried. Furthermore, a greater amount of solids are recovered in the UF filtrate (fraction 5) of the supernatant. These results are in line with those of BARRETTE and co-workers, (1999) who had shown cell lysis following freezing of bakers's yeast suspensions.

It is noteworthy that supernatants (fraction 2) obtained from the dried culture had a lower iron content than that of the fresh yeast (Table 1). This is accompanied by a lower iron content in the UF filtrate (fraction 5) of the rehydrated cells, which represents the $<1000$ mol.wt portion of the supernatant. These data suggest that the freeze-drying process has induced binding of free iron to the yeast cell wall. Indeed, iron content of the cell pellet (fraction 3) was more than twice as high when the cells had previously been freeze-dried (Table 1). Furthermore, data shows that this iron increase in cells that were freeze-dried (fraction 3) was due to binding to the cell walls (fraction 6) as well as the intracellular content (fraction 7).

Drying may impart a change in molecular conformation of the yeast cells and specific sites for metal chelation may become more available. AVERY and TOBIN (1992) as well as VOLESKY and MAY-PHILLIPS (1995) have shown that the uptake of strontium and uranium respectively, are more important in denatured yeast biomasses than in live yeasts.

The UF retentate (fraction 4) of the fresh cells proportionally (Fe\% of TS) contained less iron than the filtrate (fraction 5), but the opposite was found with the corresponding fractions obtained from the freeze-dried cells. This suggests that drying not only increased adsorption of iron on the cells but also on the compounds having mol.wt $>1000$. The solids of the UF retentate contain both the unconcentrated low molecular weight compounds $(<1000$, fraction 5$)$ and the concentrated high molecular weight components. If the proportional iron content of fraction 5 is subtracted from that in fraction 4, this would enable an estimation on the amount of iron bound to the soluble components (>1000 mol.wt) of the yeast suspension. For the freeze-dried cells, this represents approximately $16 \%$ of the iron. Thus, our results suggest that, in the freezedried product, $42 \%$ of the iron is bound, of which $28 \%$ is in the cell fractions. In view of the fact that there was only $13 \%$ with fresh yeast, the freeze-drying process significantly increases the degree of iron binding in the product. 


\section{Conclusion}

Incubating yeast cells for one hour in the presence of high concentrations of iron enabled the binding of iron to cell components. Further studies on drying methods (spray-drying or other) or conditions (temperatures) on metal binding to yeast cells are warranted, since the effect of drying proved important in increasing the binding of iron to cells and soluble compounds of mol.wt $>1000$.

The technical and scientific support of N. GARDNER, J. CONWAY and R. DEgré was greatly appreciated.

\section{References}

AVERY, S. V. \& TOBIN, J. M. (1992): Mechanisms of strontium uptake by laboratory and brewing strains of Saccharomyces cerevisiae. Appl. envir. Microbiol., 58, 3883-3889.

BarRette, J., Champagne, C. P. \& Goulet, J. (1999): Development of bacterial contamination during production of yeast extracts. Appl. envir. Microbiol., 65, 3261-3263.

BRADY, D. \& DUNCAN, J. R. (1994): Bioaccumulation of metal cations by Saccharomyces cerevisiae. Appl. Microbiol. Biotechnol., 41, 149-154.

HeGócZKI, J. (1994) Production of yeast enriched with micro-elements. Acta Microbiol. Immunol. Hung., $41,356-357$.

HegóczKi, J., SuHAJdA, A., JANZsó, B. \& VerecZKey, G. (1997): Preparation of chromium enriched yeasts. Acta Alimentaria, 26, 345-358.

Matni, G., AZani, R., Van Calsteren, M. R., Bissonnette, M. C. \& Blais, J. S. (1995): Determination of free selenomethionine in nutritional supplements by high-performance liquid chromatography coupled with thermochemical hydride generation atomic absorption spectrometry. Analyst, 120, 395-401.

MochoвA, F., O'Connor-Cox, E. S. C. \& Axcell, B. C. (1996a): Effects of yeast quality on the accumulation and release of metals causing beer instability. J. Am. Soc. Brew. Chem., 54(3), $164-171$.

Mochoba, F., O'Connor-Cox, E. S. C. \& AxCell, B. C. (1996b): Metal ion concentration and release by a brewing yeast: Characterization and implications. J. Am. Soc. Brew. Chem., 54(3), 155-163.

Morin, A., GÉRA, R. \& LEBLANC, D. (1993): Nylon-made $180 \mathrm{ml}$ grinding vessel for laboratory-scale cell disruption. J. microbiol. Methods, 17, 233-237.

Nagodawithana, T. \& GutManis, F. (1985): Method for the production of selenium yeast. U.S.A. Patent $4,530,846$.

NESTEC (1987): Minerals, What for, Where from, How much? Nestlé Products Technical Assistance. Nestley Documentation Centre ed., Vevey, Switzerland, 46 pp.

VARIMO, K., HARJU, K., EDELMANN, K. \& Korhola, M. (1983): Seleeni pitoinen hiiva. (Selenium yeast.) Kemia-Kemi, 10, 1049-1050.

VOlesky, B. \& MAY-PHILliPS, H. A. (1995): Biosorption of heavy metals by Saccharomyces cerevisiae. Appl. Microbiol. Biotechnol., 42, 797-806. 